\title{
Nitrogen fertilization in super-early cycle common bean using new sources of urea
}

\section{Adubação nitrogenada no feijoeiro comum de ciclo superprecoce utilizando novas fontes de ureia}

\section{Antonio Joaquim Braga Pereira BRAZ'; Camila Jorge Bernabé FERREIRA²; Pedro Marques da SILVEIRA ${ }^{3}$; Gustavo André SIMON ${ }^{4}$; Renato Lara de ASSIS ${ }^{5}$; Guilherme Braga Pereira BRAZ ${ }^{6}$; Renato Vieira MEDEIROS ${ }^{7}$}

\footnotetext{
${ }^{1}$ Doutor em Agronomia, Professor da Faculdade de Agronomia da Universidade de Rio Verde, Rio Verde, Goiás, Brasil. E-mail: braz@unirv.edu.rv

${ }^{2}$ Mestre em Agronomia, Doutoranda no Programa de Pós-graduação em Agronomia da Universidade Estadual de Maringá, Maringá, Paraná, Brasil. E-mail: camilajbferreira@gmail.com. "Autor para correspondência"

${ }^{3}$ Doutor em Agronomia, Pesquisador da Embrapa Arroz e Feijão, Goiânia, Goiás, Brasil. E-mail: <pedro.silveira@embrapa.br>

${ }^{4}$ Doutor em Agronomia, Professor da Faculdade de Agronomia da Universidade de Rio Verde, Rio Verde, Goiás, Brasil. E-mail: <simon@unirv.edu.br>

${ }^{5}$ Doutor em Agronomia, Professor do Instituto Federal Goiano, Iporá, Goiás, Brasil. E-mail: relassis@bol.com.br

${ }^{6}$ Doutor em Agronomia, Professor da Faculdade de Agronomia da Universidade de Rio Verde, Rio Verde, Goiás, Brasil. E-mail: <guilhermebrag@gmail.com>

${ }^{7}$ Biólogo, Mestrando no Programa de Pós-graduação em Produção Vegetal da Universidade de Rio Verde, Rio Verde, Goiás, Brasil. E-mail: <renato_biologo@hotmail.com>
}

Recebido em: 14-09-2017; Aceito em: 24-11-2017

\begin{abstract}
The efficiency of new fertilizers as a nitrogen source in super-early cycle common bean cultivars still needs to be better known. The objective was to quantify the effect of new sources and time of application of nitrogen on yield and yield components of a super-early cycle bean cultivar. The experiment was conducted in the city of Rio Verde, state of Goias, Brazil, using the experimental design of randomized blocks, in a $3 \times 3+1$ factorial scheme, with four replications. The first factor was constituted by nitrogen $(\mathrm{N})$ sources: traditional urea, zeolite-associated urea, and urea with urease inhibitor, using the dose of $80 \mathrm{~kg} \mathrm{ha}^{-1} \mathrm{~N}$. The second factor was application stages: V2, V3, and V4, that is, when $50 \%$ of the plants had the first pair of unifoliolate leaves, the first trifoliolate leaf, and the third trifoliolate leaf fully expanded, respectively. Moreover, an additional treatment was used, without $\mathrm{N}$ application (control). The cultivar used was BRS FC104, of super-early cycle, from 60 to 65 days. The following were measured: relative chlorophyll index $(\mathrm{RCl})$, plant height, first pod insertion height, number of pods per plant, number of grains per pod, mass of 100 grains and yield. There was no significant difference between sources and application stages regarding the number of pods per plant, number of grains per pod, plant height and first pod insertion height. The highest yields were obtained with the use of zeolite-associated urea, and the best application stage was V4. The use of urea with urease inhibitor did not provide an increase in grain yield compared to the control treatment.
\end{abstract}

Additional keywords: application stage; Phaseolus vulgaris; urease inhibitor; zeolites.

\begin{abstract}
Resumo
A eficiência de novos adubos como fonte de nitrogênio em cultivar de ciclo superprecoce, no feijoeiro comum, ainda necessita ser mais bem conhecida. O objetivo foi quantificar o efeito de novas fontes e época de aplicação de nitrogênio na produtividade e nos componentes de produtividade de cultivar de feijoeiro de ciclo superprecoce. O experimento foi conduzido no município de Rio Verde-GO, utilizando o delineamento experimental de blocos casualizados, em arranjo fatorial $3 \times 3+1$, com quatro repetições. O primeiro fator foi constituído por fontes de nitrogênio $(\mathrm{N})$ : ureia tradicional, ureia associada a zeólitas e ureia com inibidor da urease, utilizando a dose de $80 \mathrm{~kg} \mathrm{ha}^{-1}$ de N. O segundo fator foram estádios de aplicação: V2, V3 e V4, ou seja, quando 50\% das plantas apresentaram o primeiro par de folhas unifolioladas, a primeira folha trifoliolada e a terceira folha trifoliolada totalmente expandida, respectivamente. Além disso, foi utilizado um tratamento adicional sem aplicação de $\mathrm{N}$ (testemunha). A cultivar utilizada foi a BRS FC104, de ciclo superprecoce, de 60 a 65 dias. Foram medidos o índice relativo de clorofila (índice SPAD), altura de planta e de inserção da primeira vagem, número de vagens por planta e grãos por vagem, massa de 100 grãos e produtividade. Não houve diferença significativa entre fontes e estádios de aplicação quanto ao número de vagens por planta e grãos por vagem, altura de plantas e de inserção da primeira vagem. As maiores produtividades foram obtidas com a utilização de ureia associada a zeólitas, e o melhor estádio de aplicação foi o V4. A utilização da ureia com inibidor de urease não proporcionou aumento na produtividade de grãos, comparado ao tratamento-testemunha.
\end{abstract}

Palavras-chave adicionais: estádios de aplicação; inibidor da uréase; Phaseolus vulgaris ; zeólitas. 


\section{Introduction}

Brazil is considered the largest consumer of common bean (Phaseolus vulgaris L.) in the world, besides being the leading country in the ranking of this legume production (Ribeiro et al., 2014). Among the factors that contribute to this higher production, its broad edaphoclimatic adaptation is highlighted, which allows the cultivation of common bean throughout the year and in practically all regions of the country.

Since the common bean is a legume, it symbiotically fixes nitrogen with soil bacteria, but not in an enough amount to satisfy the plant's demand. Nitrogen management is considered difficult, since the nutrient, despite being required in greater quantity by the bean, has a complex dynamics in the soil, being easily lost by leaching or volatilization, compromising the environment and reducing management efficiency (Cunha et al., 2011).

Urea is considered the main nitrogen source used in agriculture due to its lower cost (Rech et al., 2017). However, when applied to the surface, the loss of nitrogen by ammonia $\left(\mathrm{NH}^{3+}\right)$ volatilization to the atmosphere is considered high, whose magnitude will depend on edaphoclimatic characteristics, reaching values close to $60 \%$ loss of applied nitrogen (Rochette et al., 2013).

To improve the efficiency of nitrogen fertilizers, new products are available that can minimize nitrogen losses by ammonia volatilization, by adding urease inhibitors to the fertilizer. These products can considerably reduce the loss of $\mathrm{NH}^{3+}$, allowing more time for the fertilizer to be incorporated into the soil by rain or irrigation, without the occurrence of losses. The urea inhibitor NBPT (N-(n-butyl) thiophosphoric triamide) has been tested in several countries, showing efficiency in the reduction of nitrogen losses by volatilization when compared to traditional urea use (Pereira et al., 2009; Scivittaro et al., 2010; Rech et al., 2017). NBPT prevents the urea molecule from being broken down, inactivating the enzyme urease, thus avoiding losses by volatilization (Cantarella et al., 2003).

Another alternative that has been developed with the objective of minimizing the losses of nitrogen by volatilization is the use of aluminosilicate minerals from the zeolite group in association with urea in fertilization. Werneck et al. (2012) found that the association of zeolites with urea decreased the losses by volatilization by $20 \%$, in addition to increasing the nitrogen uptake by the plants. Bernardi et al. (2010) found satisfactory results with the use of ureaassociated zeolites in the oat crop, evidenced by the increased agronomic efficiency of nitrogen. This mineral is characterized by a structure with high affinity for $\mathrm{NH}^{4+}$, protecting the ion from losses by volatilization and nitrification by microorganisms (Reháková et al., 2004).

The time of nitrogen application is also an important factor in the management of nitrogen fertilization in common bean aiming at a greater efficiency of the use of this nutrient to reach higher yields. Therefore, the choice of the correct phenological stage of application is extremely important to offer greater safety and precision for the producer in the management of nitrogen fertilization in coverage, besides increasing the plant efficiency in the use of available resources, evidencing the possibility of increasing bean yield (Binotti et al., 2014). The nitrogen supply must be performed to provide adequate plant nutrition at a time when it is still possible to increase the number of pods per plant, that is, before flowering (Carvalho et al., 2001).

The search for cultivars of an earlier cycle has deserved the attention of bean breeders in the last years, since the identification of new cultivars of early cycle is advantageous, as it allows a lower consumption of water in irrigated crops, harvest planning for periods of less rain, and the early releasing the area for crop succession (Ribeiro et al., 2014).

There is a lack of work in the literature aiming to obtain answers regarding the use of nitrogen fertilization with high-quality urea in the bean crop to mitigate the loss of nitrogen under Cerrado conditions. Moreover, there is a lack of information on the best stage of development for the application of urea to super-early cycle cultivars.

In this context, the objective was to quantify the effect of urea sources applied at different phenological stages on yield and yield components of a super-early cycle bean cultivar.

\section{Material and methods}

The experiment was conducted in the city of Rio Verde-GO, at the geographical coordinates $17^{\circ} 48^{\prime}$ south latitude and $50^{\circ} 55^{\prime}$ west longitude, at an altitude of 770 meters, with flat relief (mean slope less than $3 \%$ ). The experiment was conducted from 05/26/2016 to $08 / 05 / 2016$.

According to Köppen's classification (Köppen \& Geiger, 1928), the climate of the locality is Aw, characteristic of tropical climates, with dry winter and humid summer, with rainfall concentrated in the summer and a well-defined dry season in the winter. The annual average rainfall is $1,500 \mathrm{~mm}$, and the annual average temperature is $23^{\circ} \mathrm{C}$.

The soil of the experiment was identified as Latossolo Vermelho Distroférrico according to EMBRAPA (2013). Before the installation of the experiment, soil analysis was performed for chemical characterization in the $0-0.20 \mathrm{~m}$ layer (Table 1). The granulometric analysis showed 580,80 and $340 \mathrm{~g} \mathrm{~kg}^{-1}$ of clay, silt and sand, respectively.

The experimental design was a randomized complete block design, in a $3 \times 3+1$ factorial scheme, with four replications. The plots consisted of six rows of $5.0 \mathrm{~m}$ in length, with $0.5-\mathrm{m}$ spacing, totaling $15 \mathrm{~m}^{2}$. For the useful area, the two central rows were considered, discarding half a meter from both ends of each row, totaling $4 \mathrm{~m}^{2}$. 
Table 1 - Soil chemical characteristics of the experiment area.

\begin{tabular}{ccccccccccc}
\hline $\mathrm{pH}\left(\mathrm{CaCl}_{2}\right)$ & $\begin{array}{c}\mathrm{P}(\mathrm{Mehlich}) \\
\left(\mathrm{mg} \mathrm{dm}^{-3}\right)\end{array}$ & $\begin{array}{c}\mathrm{OM} \\
\left(\mathrm{g} \mathrm{dm}^{-3}\right)\end{array}$ & $\begin{array}{c}\mathrm{Ca}^{2+} \\
\mathrm{Mg}^{2+}\end{array}$ & $\begin{array}{c}\mathrm{K}^{+} \\
\mathrm{Al}^{3+}\end{array} \mathrm{Al}^{3+}+\mathrm{H}^{+}$ & $\mathrm{SB}$ & $\mathrm{CEC}$ & $\begin{array}{c}\mathrm{V} \\
(\%)\end{array}$ \\
\hline 5.7 & 2.13 & 2.74 & 1.57 & 0.53 & 0.27 & 0.10 & 4.70 & 2.34 & 7.04 & 33 \\
\hline
\end{tabular}

$\mathrm{OM}$ - organic matter; SB - sum of bases; CEC - cations exchange capacity; $\mathrm{V}$ - bases saturation

The treatments consisted of the combination of three nitrogen sources, three application stages, plus one control treatment, without application. Nitrogen sources were: traditional urea, zeoliteassociated urea, and urea with urease inhibitor (commercial product Agrotain ${ }^{\circledR}$ ), applied manually by broadcasting, without incorporation, at approximately $0.1 \mathrm{~m}$ of the plant rows, followed by irrigation.

Cover nitrogen fertilization was performed using the dose of $80 \mathrm{~kg} \mathrm{ha}^{-1} \mathrm{~N}$, when the bean plants reached the vegetative stages V2, V3, and V4, which were characterized as: vegetative stage V2 (when 50\% of the plants had the first pair of unifoliolate leaves fully expanded); vegetative stage V3 (when $50 \%$ of the plants had the first trifoliolate leaf fully expanded); and vegetative stage V4 (when $50 \%$ of the plants had the third trifoliolate leaf fully expanded) (Fernandez et al., 1982).

The cultivar used was BRS FC104 ("carioca" commercial group), being considered as a super-early cycle material (60 to 65 days from emergence to harvest, on average). Sowing was performed manually, on 05/26/2016, with 12 seeds per meter; the planting furrow and base fertilization were mechanically made through a fertilizer sowing machine, using $400 \mathrm{~kg} \mathrm{ha}^{-1}$ of the formula 4-20-20, carried out considering the chemical characteristics of the soil. The emergence of common bean seedlings occurred five days after sowing, on 05/31/2016.

Irrigation was performed by central-pivot sprinklers when the average of the soil water potential readings, evaluated by three tensiometers installed in the area at $0.15 \mathrm{~m}$ deep was in the range between $-30 \mathrm{kPa}$ and $-40 \mathrm{kPa}$. Phytosanitary treatments and irrigation management were carried out according to the technical recommendations for the bean crop (EMBRAPA, 2012).

In the experiment, the relative chlorophyll index $(\mathrm{RCl})$ was measured with the Minolta SPAD 502 (Soil Plant Analysis Development) chlorophyll meter. The readings with the chlorophyll meter were performed at 22 and 43 days after emergence (DAE), on 06/16/2016 and 07/07/2016, respectively, being randomly obtained in each experimental plot, in the four central rows, in the first fully expanded trifoliate, avoiding the central vein and the leaf margins, totaling 50 readings per plot.

In the field, 10 plants were randomly evaluated in the useful area of each plot, and the following variables were determined: plant height, determined by measuring the distance from the soil surface to the last pod insertion point; first pod insertion height, determined by measuring the distance from the soil surface to the first pod insertion point. Subsequently, the plants were taken to the laboratory to determine the number of pods per plant, obtained by the ratio between the total number of pods and the total number of plants; the number of grains per pod: obtained by the ratio between the total number of grains and the total number of pods; and the 100-grain weight: obtained by weighing 100 grains of each plot, with moisture correction to $13 \%$.

The bean plants were harvested on $08 / 05 / 2016$. Grain yield was obtained by weighing the grains of the useful area of each plot, with the values being extrapolated to $\mathrm{kg} \mathrm{ha}^{-1}$ and corrected to $13 \%$ moisture.

The data of the evaluated characteristics were submitted to analysis of variance, and when the effect of urea sources and phenological stages were significant, the Tukey test was applied at $5 \%$ probability for comparison means, in addition to the Dunnett test at $5 \%$ probability for comparison between treatments and the control, using the program Assistat (Silva \& Azevedo, 2009).

\section{Results and discussion}

The variables number of pods per plant, number of grains per pod, plant height, and first pod insertion height were not influenced by the different nitrogen sources or stages of nitrogen application ( $p>0.05$ ) (Table 2). Guimarães et al. (2017) also did not find differences in these same variables when evaluating the $\mathrm{N}$ doses of 40,80 , and $120 \mathrm{~kg} \mathrm{ha}^{-1}$ in common bean with urea as the traditional source, showing the difficulty of pointing out differences in these characteristics.

In the first evaluation of the relative chlorophyll index (RCl) at $22 \mathrm{DAE}$ (Table 2), the bean stage at the time of the application in coverage influenced the response of the plants to this variable. On the other hand, this behavior was not observed in the $\mathrm{RCl}$ evaluation performed at $43 \mathrm{DAE}$, since differences were verified only between the treatments and the control without nitrogen fertilization.

In the $\mathrm{RCl}$ evaluation performed at $22 \mathrm{DAE}$, it can be observed that the plants that received nitrogen sources in coverage in the V2 stage had higher values of this variable in relation to those in which the V4 application was foreseen (Table 3). The observation of this behavior is related to the fact that at the time the evaluation was carried out, nitrogen application to V4 plants was not performed since they did not reach such phenological stage. Thus, the lower values of $\mathrm{RCl}$ recorded in the plants present in these treatments are possibly reflections of a lower leaf nitrogen content. 
Table 2 - Summary of analysis of variance ( $F$ values) of agronomic characteristics, yield components and grain yield of common bean grown under different nitrogen sources ( $N$ Source) and application stages.

\begin{tabular}{lcccccccc}
\hline Sources of variation & NPP & NGP & H & HFP & RCl-22DAE & RCl-43DAE & M100 & Yield \\
\hline N Source (NS) & $1.06^{\text {ns }}$ & $0.03^{\text {ns }}$ & $0.24^{\text {ns }}$ & $1.27^{\text {ns }}$ & $3.35^{\text {ns }}$ & $0.54^{\text {ns }}$ & $3.76^{*}$ & $5.52^{* *}$ \\
Phenological Stage (PS) & $0.26^{\text {ns }}$ & $0.79^{\text {ns }}$ & $0.82^{\text {ns }}$ & $1.28^{\text {ns }}$ & $6.93^{\text {** }}$ & $0.01^{\text {ns }}$ & $1.82^{\text {ns }}$ & $4.12^{*}$ \\
NS vs PS & $0.64^{\text {ns }}$ & $1.15^{\text {ns }}$ & $1.19^{\text {ns }}$ & $0.69^{\text {ns }}$ & $1.51^{\text {ns }}$ & $0.48^{\text {ns }}$ & $5.71^{* *}$ & $0.32^{\text {ns }}$ \\
Factorial vs Control & $0.18^{\text {ns }}$ & $3.85^{\text {ns }}$ & $0.10^{\text {ns }}$ & $0.11^{\text {ns }}$ & $0.84^{\text {ns }}$ & $9.73^{* *}$ & $0.63^{\text {ns }}$ & $14.44^{*}$ \\
Residue & - & - & - & - & - & - & - & - \\
\hline Average & 14.07 & 5.36 & 34.73 & 8.55 & 38.94 & 30.48 & 25.05 & 3759.59 \\
CV (\%) & 12.82 & 8.62 & 8.98 & 21.02 & 2.59 & 8.65 & 4.95 & 9.63 \\
\hline
\end{tabular}

$\mathrm{NPP}=$ number of pods per plant; NGP = number of grains per pod; $\mathrm{H}=$ height of plants; $\mathrm{HFP}=$ height of insertion of the first pod; $\mathrm{RCl}=$ relative chlorophyll index, $\mathrm{DAE}=$ days after emergence, $\mathrm{M} 100=$ mass of 100 grains; ns Not significant; **, * Significant at 1 and $5 \%$ probability by the F Test, respectively; ${ }^{\text {ns }}$ Not significant at $5 \%$ probability by $\mathrm{F}$ test.

Table 3 - Relative chlorophyll index $(\mathrm{RCl})$ at 22 and 43 days after emergency (DAE) as a function of nitrogen source (N Source) and the phenological stage of $\mathrm{N}$ application. Rio Verde (GO), 2016.

\begin{tabular}{|c|c|c|c|c|}
\hline \multirow{3}{*}{ N Source } & \multicolumn{4}{|c|}{ (a) Phenological stage } \\
\hline & V2 & V3 & V4 & Average \\
\hline & \multicolumn{4}{|c|}{$\mathrm{RCl}-22 \mathrm{DAE}$} \\
\hline Urea with urease inhibitor & 39.41 & 38.47 & 38.13 & 38.67 \\
\hline Traditional urea & 40.04 & 38.23 & 37.25 & 38.51 \\
\hline Zeolite-associated urea & 39.66 & 39.68 & 39.16 & 39.50 \\
\hline Average & $39.70 \mathrm{~A}$ & $38.79 A B$ & $38.17 \mathrm{~B}$ & \\
\hline \multirow[t]{2}{*}{ Control } & \multicolumn{4}{|c|}{39.38} \\
\hline & \multicolumn{4}{|c|}{$\mathrm{RCl}-43 \mathrm{DAE}$} \\
\hline Urea with urease inhibitor & 30.40 & 31.25 & 29.95 & 30.53 \\
\hline Traditional urea & $32.33^{*}$ & 30.77 & 31.55 & 31.55 \\
\hline zeolite-associated urea & 29.75 & 30.91 & 31.29 & 30.65 \\
\hline Average & 30.83 & 30.98 & 30.93 & \\
\hline
\end{tabular}

(a) V2: when $50 \%$ of the plants had the first pair of unifoliolate leaves fully expanded; V3: when $50 \%$ of the plants had the first trifoliolate leaf fully expanded; V4: when $50 \%$ of the plants had the third trifoliolate leaf fully expanded; * Mean differ from the control by the Dunnett test $(p \leq 0.05)$; Means followed by the same letter, uppercase in line do not differ by Tukey test (p>0.05).

The $\mathrm{RCl}$ was also evaluated in bean plants at $43 \mathrm{DAE}$, however, its behavior was not clear, since a significant difference was observed only between the control without urea application and the traditional urea source, in V2. The $\mathrm{RCl}$ is used to estimate the chlorophyll content in plants and it is highly correlated to the nitrogen level in the leaves (Taiz \& Zeiger, 2017). The fact that nitrogen is an extremely mobile element in the plant causes the symptoms of nutritional deficiency to be expressed first in the older leaves (Taiz \& Zeiger, 2017); however, the $\mathrm{RCl}$ evaluation was performed on the first fully expanded trifoliolate leaf (younger leaves) and may have contributed to the absence of differences. Maia et al. (2017) observed the greatest differences in $\mathrm{RCl}$ between nitrogen doses when evaluating older leaves (third fully expanded leaf) of common bean compared to younger leaves.

Another important factor to consider is that the younger leaves (first fully expanded leaf) have higher levels of $\mathrm{NO}_{3}-\mathrm{N}$, which is a form that is not associated with a chlorophyll molecule, hindering the evaluation of the nutritional status of plants through $\mathrm{RCl}$, which often presents inconclusive results (Dwyer et al., 1995).

Mass of 100 grains was the only yield component affected by the different treatments evaluated, with effect of both the different nitrogen sources and their interaction with the stage of bean plants at the time of application. Finally, for the bean grain yield data, there was an effect of the isolated factors, with no influence of the interaction between nitrogen sources and application stage on this variable.

The variable mass of 100 grains is a characteristic of great importance to the consumer market and is strongly influenced by the environment (Perina et al., 2010; Pereira et al., 2012). The weight variation among the treatments tested ranged from $24.14 \mathrm{~g}$ (zeolite-associated urea, at the V2 stage) to $27.23 \mathrm{~g}$ (urease inhibitor, at the V4 stage) (Table 4). This characteristic showed a significant difference between the nitrogen sources, and there was a significant interaction between source and stage, that is, nitrogen sources influenced the mass of 100 grains differently for each stage, as observed in Table 4. 
Table 4 - Mass of 100 grains and common bean yield as a function of nitrogen source and application stage.

\begin{tabular}{|c|c|c|c|c|}
\hline \multirow{3}{*}{ N Source } & \multicolumn{4}{|c|}{ (a) Phenological stage } \\
\hline & $\mathrm{V} 2$ & V3 & V4 & Average \\
\hline & \multicolumn{4}{|c|}{ Mass of 100 grains $(\mathrm{g})$} \\
\hline Urea with urease inhibitor & $24.37 \mathrm{aB}$ & $25.24 a b A B$ & $27.23 \mathrm{aA}$ & 25.61 \\
\hline Traditional urea & $25.23 \mathrm{aA}$ & $24.55 \mathrm{bA}$ & $23.15 \mathrm{bA}$ & 24.31 \\
\hline Zeolite-associated urea & $24.14 \mathrm{aB}$ & $26.82 \mathrm{aA}$ & $25.15 a b A B$ & 25.37 \\
\hline Average & 24.58 & 25.54 & 25.17 & - \\
\hline \multirow[t]{2}{*}{ Control } & \multicolumn{4}{|c|}{24.58} \\
\hline & \multicolumn{4}{|c|}{ Yield $\left(\mathrm{kg} \mathrm{ha}^{-1}\right)$} \\
\hline Urea with urease inhibitor & 3.328 & 3.579 & 3.797 & $3.569 \mathrm{~b}$ \\
\hline Traditional urea & 3.586 & $3.888^{*}$ & $4.144^{*}$ & $3.873 \mathrm{ab}$ \\
\hline Zeolite-associated urea & $3.989^{*}$ & $3.947^{*}$ & $4.228^{*}$ & $4.055 \mathrm{a}$ \\
\hline Average & $3.635 \mathrm{~B}$ & $3.805 \mathrm{AB}$ & $4.057 \mathrm{~A}$ & - \\
\hline
\end{tabular}

(a) V2: when $50 \%$ of the plants had the first pair of unifoliolate leaves fully expanded; V3: when $50 \%$ of the plants had the first trifoliolate leaf fully expanded; V4: when $50 \%$ of the plants had the third trifoliolate leaf fully expanded; * Mean differ from the control by the Dunnett test $(p \leq 0.05)$; Means followed by the same letter, uppercase in line and lowercase in column, do not differ by Tukey test $(p>0.05)$.

It is important to note that as it is a new cultivar, there are still no reports in the literature for grain size comparison, so it was not possible to say if the values found were above or below the average for the genotype evaluated in the experiment. However, due to the fact that this experiment reached satisfactory yield values (average of $3,832 \mathrm{~kg} \mathrm{ha}^{-1}$ ), probably the values of mass of 100 grains found are near the real value of this cultivar.

When using urea with urease inhibitor as a nitrogen source, the mass of 100 grains showed no differences between the V4 and V3 stages, as well as between V3 and V2. However, urea with urease inhibitor promoted a higher weight when applied at the V4 stage compared to V2, in addition to higher values for the application stage V4 when compared to V2, although not differing from V3, suggesting that as the development stages advance, the application of urea with urease inhibitor tends to increase the mass of 100 grains. When using zeolite-associated urea as a source, regarding the application stage, there were no differences between the stages V3 and V4, as well as between V4 and V2. Nonetheless, the application stage V3 provided a higher mass of 100 grains when compared to the V2 stage.

These results suggest that when the nitrogen source used is urea associated with urease inhibitor, the application in more advanced vegetative stages for the cultivar tested (BRS FC104) promoted a higher efficiency of the fertilization, which reflected in grain weight gain, and could be considered a good alternative for bean sowing in the state of Goias. On the other hand, for the use of traditional urea, the application stage did not influence the mass of 100 grains, agreeing with the results found by Guimarães et al. (2017), who did not find a response of the mass of 100 grains when evaluating different stages of application of traditional urea in common bean. Furthermore, it is observed that the mass of 100 grains tends to decrease as the plant grows.

The mass of 100 grains did not present significant difference between the nitrogen sources for the V2 stage, demonstrating that when the application is carried out at the initial stage of development of the bean crop, the nitrogen source has no influence on grain weight gain, with all sources behaving in a similar way. On the other hand, when the application is made at the V3 development stage, the use of zeoliteassociated urea promoted the highest mass of 100 grains when compared to the traditional urea source, whereas in V4, the source with urease inhibitor obtained the best performance when compared to the use of traditional urea.

The urea sources associated both with zeolites and with urease inhibitor have proven efficiency in the literature regarding the reduction of nitrogen losses by volatilization when compared to the use of traditional urea (Pereira et al., 2009; Scivittaro et al., 2010; Werneck et al., 2012; Rech et al., 2017). In this way, the plant can absorb more nutrients, contributing to greater grain weight in these treatments.

Grain yield ranged from 3,107 (control without application of nitrogen source) to $4,228 \mathrm{~kg} \mathrm{ha}^{-1}$ (zeoliteassociated urea, at the V4 application stage), highlighting that all treatments showed yields higher than the average of bean plants from the third harvest in Goias in this period, which was $2,872 \mathrm{~kg} \mathrm{ha}^{-1}$ (CONAB, 2017). This high yield is probably associated to the regular use of irrigation during the period of conduction of the experiment, which contributed to a higher nitrogen uptake, favoring yield components.

For the variable yield, there was a difference between the isolated factors source and stage, with the highest yield value $\left(4,055 \mathrm{~kg} \mathrm{ha}^{-1}\right)$ being verified when using zeolite-associated urea (Table 4) was better than 
the source of urea with urease inhibitor. This result is probably associated to the effect of zeolite on the reduction of ammonia volatilization losses, which contributed to a higher efficiency of nitrogen fertilization and increased $\mathrm{N}$ uptake by plants as observed by Werneck et al. (2012). In contrast, Rech et al. (2017) found no decrease in loss by volatilization with zeolite addition.

Regarding the application stage, a higher yield was achieved when the application was made at V4 $\left(4,056 \mathrm{~kg} \mathrm{ha}^{-1}\right)$, however, it did not differ significantly from the application performed at the V3 stage. On the other hand, Meira et al. (2005), when evaluating times of nitrogen application in irrigated bean, did not find a relationship between the application time and the response in yield and yield components.

Bean grain yield in the control treatment, without nitrogen application, was $3,107 \mathrm{~kg} \mathrm{ha}^{-1}$. As already presented, this yield is considered high, being higher than the national average for the crop. Possibly, this behavior observed in the experiment may be related to the preceding crop that was explored, which was soybean, a species with high biological nitrogen fixation.

When comparing the treatments with the application of traditional urea at V2 and urea with urease inhibitor at all the evaluated stages, it is verified that they did not differ for yield in relation to the control, demonstrating that these options were not constituted as good alternatives aiming at nitrogen fertilization in coverage for the bean crop. The use of urea with urease inhibitor also showed no difference compared to the use of traditional urea. This corroborates the results found by Cunha et al. (2011) and Bernardes et al. (2015), who also observed no effect of the use of urea with urease inhibitor compared to traditional sources of nitrogen. However, the use of traditional urea at V3 and V4, and zeolite-associated urea at any application stage evaluated provided higher yields for the bean crop when compared to the control treatment.

\section{Conclusion}

In the bean crop, the yield components number of pods per plant, number of grains per pod, plant height, and first pod insertion height were not influenced by the different sources and stages of application of nitrogen in coverage.

The super-early cycle bean cultivar BRS FC104 obtained higher yield values with the use of zeolite-associated urea, and the best stage of application of nitrogen fertilization was V4.

\section{Acknowledgements}

We thank Embrapa Arroz e Feijão for supplying the seeds of the new bean cultivar. We also thank the Universidade de Rio Verde - UniRV for granting the research scholarship, which made possible the execution of this work.

\section{References}

Bernardes TG, Silveira PM, Carvalho MTM, Madari BE, Carvalho MCS (2015) Produtividade do feijoeiro irrigado em razão de fontes de adubo nitrogenado estabilizado e de liberação controlada. Revista Ceres 62(4):614-620.

Bernardi ACC, Monte MBM, Paiva PRP (2010) Produção de matéria seca, extração e utilização de nitrogênio em aveia adubada com ureia misturada com zeólita. Revista Agricultura 8(1):1-10.

Binotti FFS, Arf O, Cardoso ED, Sá ME, Buzetti S (2014) Manejo do nitrogênio em cobertura do feijoeiro de inverno no sistema plantio direto. Revista de Agricultura Neotropical 1(1):58-64.

Cantarella H, Mattos Junior D, Quaggio JA, Rigolin AT (2003) Fruit yield of Valencia sweet orange fertilized with different $\mathrm{N}$ sources and the loss of applied $\mathrm{N}$. Nutrient Cycling in Agroecosystems 67(3):205-213.

Carvalho MAC, Arf O, Sá ME, Buzetti S, Santos NCB, Bassan DA (2001) Produtividade e qualidade de sementes de feijoeiro (Phaseolus vulgaris L.) sob influência de parcelamentos e fontes de nitrogênio. Revista Brasileira de Ciência do Solo 25(4):617-624.

Companhia Nacional de Abastecimento - CONAB. Acompanhamento da safra brasileira de grãos, Safra 2016/17. Brasília, 176p.

Cunha PCR, Silveira PM, Ximenes PA, Souza RF, Alves Júnior J, Nascimento JL (2011) Fontes, formas de aplicação e doses de nitrogênio em feijoeiro irrigado sob plantio direto. Pesquisa Agropecuária Tropical 41(1):80-86.

Dwyer LM, Anderson AM, Stewart DW, Tollenaar M, Gregorich E (1995) Quantifying the nonlinearity in chlorophyll meter response to corn leaf nitrogen concentration. Canadian Journal of Plant Science 75(2):179-182.

EMBRAPA (2012). Empresa Brasileira de Pesquisa Agropecuária. Informações técnicas para o cultivo do feijoeiro-comum na Região Central Brasileira: 2012-2014. Santo Antonio de Goiás, 247p.

EMBRAPA (2013) Empresa Brasileira de Pesquisa Agropecuária. Centro Nacional e Pesquisa em Solos. Sistema brasileiro de classificação de solos, Brasília. $353 p$.

Fernandez F, Gepts P, Lopes M (1982) Etapas de desarollo de la planta de frijol comum. Cali: Centro Nacional de Agricultura Tropical. 26 p. 
Guimarães RAM, Braz AJBP, Simon GA, Ferreira CJB, Braz GBP, Silveira PM (2017) Resposta de cultivares de feijoeiro a adubação nitrogenada em diferentes estádios fenológicos. Global Science and Technology 10(1):136-148.

Köppen W, Geiger R (1928) Klimate der Erde. Gotha: Verlag Justus Perthes.

Maia SCM, Soratto RP, Liebe SM, Almeida AQ (2017) Criteria for topdressing nitrogen application to common bean using chlorophyll meter. Pesquisa Agropecuária Brasileira 52(5):512-520.

Meira FA, Sá ME, Buzetti S, Arf O (2005) Doses e épocas de aplicação de nitrogênio no feijoeiro irrigado cultivado em plantio direto. Pesquisa Agropecuária Brasileira 40(4):383-388.

Pereira HS, Almeida VM, Melo LC, Wenland A, Faria LC, Peloso MJD, Magaldi MCS (2012) Influência do ambiente em cultivares de feijoeiro-comum em cerrado com baixa altitude. Bragantia 71(2): 165-172.

Pereira HS, Leão AF, Verginassi A, Carneiro MAC (2009) Ammonia volatilization of urea in the out-ofseason corn. Revista Brasileira de Ciência do Solo 33(6):1685-1694.

Perina EF, Carvalho CRL, Chiorato AF, Gonçalves JGR, Carbonell SAM. (2010) Avaliação de estabilidade e adaptabilidade de genótipos de feijoeiro (Phaseolus vulgaris L.) baseada na análise multivariada da performance genotípica. Ciência e Agrotecnologia 34(3):398-406.

Reháková $M$, Cuvanová $S$, Dzivák $M$, Rimár J, Gaval'ová Z (2004) Agricultural and agrochemical uses of natural zeolite of the clinoptilolite type. Current Opinion in Solid State and Materials Science 8(3):397-404.
Rech I, Polidoro JC, Pavinato PS (2017) Additives incorporated into urea to reduce nitrogen losses after application to the soil. Pesquisa Agropecuária Brasileira 52(3):194-204.

Rochette $\mathrm{P}$, Angers DA, Chantigny $\mathrm{MH}$, Gasser $\mathrm{MO}$, Macdonald JD, Pelster DE, Bertrand N (2013) NH3 volatilization, soil $\mathrm{NH} 4+$ concentration and soil $\mathrm{pH}$ following subsurface banding of urea at increasing rates. Canadian Journal of Soil Science 93(2):261-268.

Ribeiro ND, Domingues LS, Gruhn EM, Zemolim AEM, Rodrigues JA (2014) Desempenho agronômico e qualidade de cozimento de linhagens de feijão de grãos especiais. Revista Ciência Agronômica 45(1):92100.

Silva FAS, Azevedo CAV (2009) Principal Components Analysis in the Software AssistatStatistical Attendance. In: WORLD CONGRESS ON COMPUTERS IN AGRICULTURE, 7, Reno-NV-USA: American Society of Agricultural and Biological Engineers.

Scivittaro WB, Gonçalves DRN, Vale MLC, Ricordi VG (2010) Perdas de nitrogênio por volatilização de amônia e resposta do arroz irrigado à aplicação de ureia tratada com o inibidor de uréase NBPT. Ciência Rural 40(6):1283-1289.

Taiz L, Zeiger E (2017) Fisiologia vegetal. 6.ed. Porto Alegre: Artmed, 888p.

Werneck CG, Breda FA, Zonta E, Lima E, Polidoro JC, Balieiro FC, Bernardi ACC (2012) Volatilização de amônia proveniente de ureia com zeolita natural. Pesquisa Agropecuária Brasileira 47(5):466-470. 